\title{
EPIDEMIOLOGICAL SIGNIFICANCE OF SALMONELLA ENTERICA SEROVAR MONTEVIDEO AND THE POTENTIAL ROLE OF FEED FOR THEIR ENTRY INTO THE FOOD CHAIN
}

\author{
Dubravka S. Milanov ${ }^{1 *}$, Maja J. Velhner ${ }^{1}$, Neđeljko R. Karabasil ${ }^{2}$, Ivana S. Čabarkapa ${ }^{3}$, \\ Ljiljana Đ. Suvajdžić ${ }^{4}$ \\ ${ }^{1}$ Scientific Veterinary Institute „Novi Sad“, 21000 Novi Sad, Rumenački put 20, Serbia \\ ${ }^{2}$ University of Belgrade, Faculty of Veterinary Medicine, 11000 Belgrade, \\ Bulevar oslobođenja 18, Serbia \\ ${ }^{3}$ University of Novi Sad, Institute of Food Technology, 21000 Novi Sad, Bulevar cara Lazara 1, Serbia \\ ${ }^{4}$ Faculty of Medicine, Department of Pharmacy, 21000 Novi Sad, Hajduk Veljkova 3, Serbia
}

\author{
*Corresponding author: \\ Phone: +381214895346 \\ Fax: +38121518544 \\ E-mail address: dubravka@niv.ns.ac.rs
}

\begin{abstract}
Animal feed is the first link in the food chain and one of the possible source of Salmonella for food producing animals and consequently, humans consuming products of animal origin. The assessment of the importance and role of Salmonella organisms commonly detected in animal feed in epidemic outbreaks of salmonellosis is highly intricate. This is mainly due to the fact that isolates are rarely identified (typed) to the serovar level, thus, the relevant data on both animal feed and food of animal origin are lacking. In the framework of the 2-year project granted by the Ministry of Science and Technological Development of the Republic of Serbia, all Salmonella isolates originating from animal feed were typed to the serovar level in the National Reference Laboratory for Salmonella. Eighteen different serovars have been identified, whereas $15 \%$ of all isolates included serovar Montevideo. Frequent isolation of $S$. ser. Montevideo from animal feed originating from feed mills in our epizootic area (South Bačka and Srem district), encouraged our attempt to summarize and present the available data on the importance of Montevideo serovar in the outbreaks of clinical salmonellosis in humans and to review the reports on individual epidemiological studies aimed at detecting infection sources and establishing relevant facts on emerging antimicrobial resistance of Salmonella. Moreover, this article emphasizes the need and importance of an extensive Salmonella monitoring program at national level, which would encompass all links of the food chain including animal feed and feed processing plants as well.
\end{abstract}

Key words: animal feed, food chain, Salmonella ser. Montevideo

\section{INTRODUCTION}

Food represents an important source of pathogenic organisms, and industrial production of food resulted in increased incidence of foodborne diseases as well as their wider geographic spreading and increased severity of complications. Only during 2013, in the United States, 818 foodborne disease outbreaks were reported, resulting in 13,360 illnesses, 1,062 hospitalizations, and 16 deaths (CDC, 2013). Among the foodborne pathogens, Salmonella enterica is one of the most devastating pathogens (Gieraltowski et al., 2013). Salmonellosis is responsible for $11 \%$ all food related deaths (Allard et al., 2012), and the incidence of salmonellosis in the human population has not been decreasing during the past decade (Brendan et al., 2013). Manual for reporting on food-borne outbreaks (EFSA, 2015) recommends that severity of disease can be characterized by reporting the number of deaths and hospitalizations. For example, in food-borne infections, the 
incidence of viral infections is three and four times higher than that of salmonelosis and campylobacteriosis, respectively. However, the number of salmonellosis-associated hospitalizations is two times higher than that related to campylobacteriosis, and almost four times higher as compared with foodborne viral infections. According to the report of European Food Safety Authority, in the period 2007-2011, 1,271 salmonellosis epidemics were recorded involving 17,001 diseased humans, 3,208 hospitalizations and 24 lethal outcomes (EFSA, 2013). According to the report of the Institute of Public Health of Serbia, the number of registered cases in Serbia in 2012 is as following: 1,494 cases of enteritidis salmonellosa (1,093 in central Serbia and 401 in Vojvodina); 2 cases of salmonellosis septica (in Vojvodina) and 54 cases of salmonellosis non specificata (47 in central Serbia and 7 in Vojvodina) (Institut za javno zdravlje Srbije, 2012).

\section{Genus Salmonella - general information}

Molecular methods have shown that the genus Salmonella comprises only two species: S. enterica and S. bongori. Salmonella enterica is further subdivided into six subspecies, which are designated by numbers: $S$. enterica subsp. enterica (subspecies I), $S$. enterica subsp. salamae (subspecies II), S. enterica subsp. arizonae (subspecies IIla), S. enterica subsp. diarizonae (subspecies IIlb), S. enterica subsp. houtenae (subspecies IV) and $S$. enterica subsp. indica (subspecies $\mathrm{VI}$ ). Salmonella serotyping is based on lipopolysaccharides $(\mathrm{O})$, flagellar proteins $(\mathrm{H})$ (flagellar antigens phase 1; flagellar antigens phase 2 (if present)), and capsular (Vi) antigens. So far, 2,579 Salmonella serotypes are known, out of which 2,557 belong to the subspecies $S$. enterica and 22 to subspecies S. bongori (Grimont and Weill, 2007). S. enterica subsp. enterica (or subspecies I) includes serovars that are most commonly isolated in humans and farm animals (e.g., S. Enteritidis group $0: 9$ (D1) and $S$. Typhimurium-group $\mathrm{O}: 4(\mathrm{~B})$ ), which are of greatest epidemiological importance and thus mostly investigated serovars. Salmonella enterica subsp. enterica serovar Montevideo, which is addressed in this article, belongs to the group 0:7 (C1). Its antigenic formula is:
6,$7 ; \mathrm{g}, \mathrm{m}, \mathrm{s} ;[1,2,7]$.

\section{Food as a source of Salmonella}

Being a first link in the food chain, animal feed is a potential reservoir of Salmonella. Salmonella from animal feed can colonize or cause infection in food producing animals and, consequently, in humans consuming food of animal origin. Several studies demonstrated that animal feed can represent the reservoir for particular strains responsible for outbreaks of human salmonellosis (Crump et al., 2002; Jones, 2011). However, revealing of the infection source in salmonellosis is very difficult, and especially source tracing analysis to the farm-level or to the feed-mills. This is mainly due to the fact that isolates are rarely identified (typed) to the serovar level, thus, the relevant data on both animal feed and food of animal origin are lacking. According to the Food and Drug Administration (FDA), in the researches dating from 1993 , only $23 \%$ Salmonella isolates from animal feed were identified to serotype level (McChesney et al., 1995). On the other hand, the sources of Salmonella for people are numerous and heterogeneous, reaching far beyond the pro-ducts of animal origin. Some recent epidemiological researches increasingly identify the food of plant origin as a source of infection. Plant colonization by Salmonella enterica has recently been established, whereas $S$. ser. Typhimurium actively invades plant tissues causing a range of disease symptoms (Lapidot et al., 2006; Steenackers et al., 2012; CevallosCevallos et al., 2012). Potential sources of salmonellas include "vegetables (tomatoes and peppers), fresh herbs, types of whole, fresh, pulped, frozen or juiced fruits, salads and other leafy greens, nuts, seeds and derived products, e.g. almonds, peanuts, coconut and sesame seeds, corn or rice snacks" (EFSA, 2013).

In the framework of the project granted by the Ministry of Science and Technological Development of the Republic of Serbia, throughout the 2-year period, all Salmonella isolates originating from animal feed were submitted for confirmation and serotyping to the National Reference Laboratory for Salmonella, Shigella, Vibrio cholereae and Yersinia enterocolitica of the Institute of Public Health of Serbia „Dr 
Milan Jovanović Batut“. Eighteen different serovars have been identified, whereas $15 \%$ of all isolates included serovar Montevideo. As compared to 5 Salmonella serovars, which are subject of special control measures in our country $(S$. ser. Enteritidis, $S$. ser. Typhimurium, $S$. ser. Hadar, S. ser. Infantis and $S$. ser. Virchow), little is known about the serovar Montevideo. Along with $S$. ser. Senftenberg and S. ser. Agona, $S$. ser. Montevideo is considered „feed adapted" Salmonella serovar and is frequently isolated in feed and feed industry (Vestby et al., 2009; Nesse et al., 2003). In the U.S.A., it is one of the top ten most common Salmonella serovars in foods (Allard et al., 2012). Having in mind frequent isolation of $S$. ser. Montevideo from animal feed from feed factories and feed mills in the regions of South-Bačka and Srem, this article presents the available relevant data on this serovar and its role and importance in outbreaks of clinical salmonellosis.

\section{S. enterica subsp. enterica serovar Montevideo - epidemiological data}

$S$. ser. Montevideo is potential causative agent of human and animal diseases (Kim et al., 2004). It is responsible for abortions in sheep, and in Great Britain it is considered endemic in sheep (www.gov.uk) government/uploads/system/uploads/attah ment_data/file/348960/pubsalm13-chp3).

Besides abortions, infections associated with this serovar can lead to malaise, diarrhea and death. Human infections commonly result in gastroenteritis and diarrhea, and some further symptoms include nausea, abdominal cramp and vomiting (Lawlor and Reinert, 2013). Typically non-typhoid Salmonellae (NTS) usually cause self-limiting diarrhea. However, under certain conditions, NTS can cause localized organic infections or bacteremia, where immune status of the host is of critical importance for the outcome of the disease. Non-typhoid Salmonella bacteremia is common in patients with reduced neutrophile granulocytes count, which emphasizes their crucial role in innate immune defense against the invading organism (Pilsczek et al., 2005). In human medicine, epidemic outbreaks associated with $S$. ser. Montevideo have been reported worldwide. Epidemiological studies of individual cases aimed at identifying the infection source demonstrated somewhat inconsistent success.

According to available data, Salmonella ser. Montevideo is considered responsible for $0.1 \%$ of all human salmonelloses in Germany. During 2008 and 2009, 65 and 38 cases of human infections associated with this serovar were reported (Stocker et al., 2011). Thus, an epidemic caused by $S$. ser. Montevideo was reported in women in Germany in 2010. The analysis identified herbal food supplement (the product advertised for relieving menopausal symptoms) as the source of infection (Stocker et al., 2011). In 1996, an epidemic of $S$. ser. Montevideo was reported in Great Britain, and the infection was associated with consuming cooked chicken bought from a supermarket (Threlfall et al., 1999). Poisoning associated with diarrhea and fever was reported in 23 patients aged 5979 in a club for elderly persons in Japan (Hamada et al., 2002). S. ser. Montevideo was isolated from stool specimens of 12 patients. In 2013, Lincoln County Health Department reported on salmonellosis outbreak in participants of private graduation party (Lawlor and Reinert, 2013). Incubation period was 10 to $44 \mathrm{~h}$, and duration of illness ranged from 1 to 11 days. Since the host of the party was chicken owner, cloacal swabs, as well as the specimens from chicken litter, fresh chicken feces and soil were collected; however, $S$. ser. Montevideo has not been isolated from any of samples. The source of infection remained unidentified. In the U.S.A., S. ser. Montevideo infection diagnosed in 93 persons in 2012, was linked with the direct contact with live poultry (CDC, 2012). According to the report of National Reference Laboratory for Salmonella in Serbia for the period 1999 - 2010, $S$. ser. Montevideo was reported as causative agent of human salmonellosis in Serbia only in 2004 (ranked 11 on the list) (World Health Organization, 2015).

\section{The importance of molecular methods in the identification of infection source}

In the past, the route from field to fork was much shorter, the food was consumed locally and salmonellosis outbreaks were limited to local epidemics (Gieraltowski et al., 2013). However, industrialized food production and intensive food trading at 
both national and international level resulted in occurrence of extensive infections spreading through several countries. Identification of such infections requires a laboratory based subtype surveillance (Gieraltowski et al., 2013). Foods involving several different ingredients pose a particular challenge in the identification of infection source. Potential salmonellacontamination of one specific ingredient is extremely difficult to confirm, since the level of contamination can be very low and the portion of this particular ingredient in different foods is variable. For example, in the period from 1 July 2009 to 14 April 2010,272 cases of human S. ser. Montevideo infections were reported in 44 U.S.A. states (CDC, 2010). A comprehensive investigation aimed at identifying the source of the epidemics was performed in all states. All determined genetic profiles of $S$. ser. Montevideo isolates were submitted into the Pulse-Net. Salami products contaminated with $S$. ser. Montevideo via the spices (black and red pepper) added to the final product after the critical control points for pathogen reduction, were identified as the infection source. However, since $S$. ser. Montevideo is a highly clonal Salmonella serotype, epidemiological investigation using pulsed-field gel electrophoresis (PFGE) is limited in its ability of differentiating strains implicated in an epidemic outbreak. Thus, genetic similarity between isolates from black and red pepper with clinical isolates was confirmed using molecular next-generation sequencing techniques (Gieraltowski et al., 2013). Next-generation sequencing (NGS) is a new technology producing dramatic advancement in molecular investigation of epidemics associated with contaminated food. The method enables investigation of genetic relatedness of clinical isolates, food-contaminating isolates and their environmental counterparts (Allard et al., 2012). This research once more emphasized the importance of a traceback to the source of contamination of final products and the role of microbiological examination of individual food ingredients. EFSA defined the specific guidance for reporting foodborne outbreaks under the framework of Directive 2003/99/EC (EFSA, 2015). Directive 2003/99 European Commission
(EC) has been imple-mented by the European Union obligating the Member States to collect data and report on zoonoses, foodborne epidemics and antimicrobial resistance. The reporting format was formerly known as Community Outbreak Reporting System (CORS), which underwent particular revisions and update, in line with the experiences from the period 20072009. Currently, the surveillance system is known as European Union Foodborne Outbreak Reporting System (EUFORS) and was implemented for the first time in the report from 2010. EFSA Manual (2015) offers guidelines on reporting foodborne disease and classifying the causative agents on the basis of real examples. One of such examples is the occurrence of human gastroenteritis caused by $S$. ser. Montevideo. This serovar was identified in feces specimens from diseases persons. Chicken nuggets were identified as infection source. The analysis of brand $A$ of these products revealed presence of $S$. ser. Enteritidis, yet not the $S$. ser. Montevideo. This example indicates that in spite of negative results on the presence of $S$. ser. Montevideo in the analyzed samples, its presence in food consumed by the diseased patients cannot be ruled out. The causative agent of the diseases to be reported was $S$. ser. Montevideo, while $S$. ser. Enteritidis was a secondary finding (EFSA, 2015).

There is a body of evidence on cases of nosocomial infections related to $S$. ser. Montevideo. In 1984. in Germany, S. ser. Montevideo infection was reported in 26 babies hospitalized for various reasons (Gericke et al., 1988). The isolates from the feces of diseased infants manifested variable antimicrobial resistance (ranging from susceptible to multiple resistant). Further research confirmed that multiple resistance of individual $S$. ser. Montevideo isolates relies on plasmid-mediated resistance, whereas same plasmids were identified in the isolates of Escherichia coli and Klebsiella from the fecal flora of diseased babies. This finding pointed out the importance of plasmid transfer from $E$. coli or Klebsiella to $S$. ser. Montevideo under in vivo conditions (Gericke et al., 1988). In 2004, S. ser. Montevideo bacteremia was reported in a three-year old girl (Kim et al., 2004). Empirical antimi- 
crobial therapy based on ampicillin/gentamycin combination did not result in any improvement. The agent was isolated from the blood and feces, and antibiotic susceptibility testing of the isolate revealed multiple resistance to cefoxitin, gentamicin, piperacillin, cefuroxime, ceftazidime and cefotaxime. According to the available literature, this is the first report on an isolate of this serotype on harboring the DHA-1, a plasmid responsible for its resistance to AmpC $\beta$-lactamase. The resistance towards ceftazidime and cefotaxime is transferred by conjugation to the recipient E. coli J53 (Kim et al., 2004). AmpC $\beta$-lactamases are primarily chromosomal cephalosporinases. $\beta$-lactam resistance mediated by plasmid-mediated AmpC $\beta$-lactamases was described in several clinical isolates of $S$. ser. Enteritidis (Gaillot et al., 1997; Barnaud et al., 1998). Plasmid exchange between enteric bacteria is an issue of paramount public health importance because of multiple plasmid-mediated resistance to antibiotics in non-typhoid Salmonella strains. A range of mobile elements are of importance in the evolution of Salmonella and the development of its antimicrobial resistance (Switt et al., 2012). The majority of researchers are focused on mobile elements in highly virulent strains (e.g., serovars Typhi, Typhimurium) or strains manifesting multiple antimicrobial resistance. Some recent researches identified novel plasmids in $S$. ser. Montevideo isolates, i.e., IncHI and an IncN2, which both encode antimicrobial resistance genes (Switt et al., 2012).

\section{CONCLUSION}

The lack of accurate and reliable data on the prevalence of diverse Salmonella serovars in animal feed, food and clinical material originating from animals is clearly evident. The Regulation on the Program of measures of animal health care in 2015 (Official Gazette of the Republic of Serbia, dated 03/04/2015) rules the "implementation of measures in case of sus-pected and confirmed cases of $S$. Ente-ritidis and S. Typhimurium, i.e., S. Hadar, S. Infantis or $S$. Virchow". Moreover, the Regulation defines the following: "with an aim of identifying all salmonellas of importance for public health, the report on the obtained re- sults must encompass both all serotypes regulated in this Regulation and other relevant regulations and all other serotypes identified".

However, identification of all serotypes in our laboratories is not feasible, which is due to lack of trained personnel and sera for identification of somatic and flagellar antigens. Identification of Salmonella isolates commonly involves identification at species level (biochemical tests), group assignment using serotyping (commonly groups B (O:4), C1 (O:7), C2-C3 (O:8), D1 $(O: 9)$ and $E(O: 1,3,19)$ and identification of five serovars of particular importance: $S$. Enteritidis, S. Hadar, S. Infantis, S. Virchow and $S$. Typhimurium. Serological identification of other serovars requires the services of the National Reference Laboratory for Salmonella, Shigella, Vibrio cholereae and Yersinia enterocolitica of the Institute of Public Health of Serbia „Dr Milan Jovanović Batut". The price of the serotyping of one isolate greatly overcomes the costs of isolation and identification of Salmonella organisms from animal feed in line with the standard SRPS EN ISO 6579:2008 (Horizontal method for isolation and identification of Salmonella spp.), which is stipulated in the general price list of the Veterinary Chamber of Serbia. In that respect, routine laboratory practice does not implicate submission of isolates to the referent laboratory for serotyping and, consequently, broad monitoring and accurate data on the prevalence of particular serovars in Serbia, are still lacking. Moreover, the surveillance of the facilities in feed production plants and animal feed itself is highly under-developed and inadequately integrated with the surveillance of microbial contamination of food of animal origin for human consumption. Thus, data that could as-sociate particular links of the food chain with the occurrence of human alimentary infections are not available. Having in mind sample number of serovars identified in the epidemics of human salmonellosis in Serbia, the strategies for reduction of salmonellosis have to be aimed at not only limited number but to all Salmonella serovars. Most frequently isolated serovars isolated from animal feed usually differ from human-derived clinical isolates; however, importance of animal feed in the 
epidemiology of salmonellosis must not be excluded. On the one hand, the reservoirs of human infections are much more heterogeneous, and on the other hand $S$. enterica strains from animal feed are commonly not typed to serovar level. Also, infective doses for humans and animals are different, and a number of cases remain unreported as the disease resolves through a course of a single self-limited infection. $S$. ser. Montevideo is frequently isolated from animal feed in our epizootic region (South Bačka and Srem district), but lack of relevant data does not allow any conclusions on its potential implication in outbreaks of human salmonellosis. The fact that animals intended for human consumption are significantly exposed to serovar Montevideo is well established. In spite of its relatively low pathogenic potential, this serovar might be of importance for the occurrence and outbreak of infections in humans. Moreover, literature data pointed out the possibility of transferring mobile genetic elements encoding antimicrobial resistance from other enteric bacteria to Salmonellae (including $S$. ser. Montevideo). Livestock industry in Serbia is characterized by an excessive application of antibiotics in both prophylaxis and therapy, which stimulates the development of new resistance mechanisms of Salmonella organisms and introduction of highly resistant strains into the food chain.

Finally, it is to be emphasized that serotypes $S$. Enteritidis and $S$. Infantis, wellestablished agents of human salmonellosis, were ranked as third and fourth most commonly isolated strains in animal feed from South Bačka and Srem district. Monitoring Salmonella has to be comprehensive, and cover all the links in the food chain starting from animal feed and facilities for their production as well.

\section{ACKNOWLEDGMENT:}

This work is supported by a grant from the Ministry of Education, Science and Technological Development, Republic of Serbia, Project number TR 31071.

\section{REFERENCES}

1. Allard, M.W., Luo, Y., Strain, E., Li, C., Keys, C.E., Son, I., Stones, R., Musser, S.M., Brown, E.W. (2012). High resolution clustering of Salmonella enterica serovar Montevideo strains using a next-generation sequencing approach. BMC Genomics, 13, 32.

(http://www.biomedcentral.com/1471 2164/13/32).

2. Barnaud, G., Arlet, G., Verdet, C., Gaillot, O., Lagrange, P.H., Philippon, A. (1998). Salmonella enteritidis: AmpC plasmid mediated inducible $\beta$-lactamase (DHA-1) with an ampR gene from Morganella morganii. Antimicrobia Agents and Chemotherapy, 42, 2352-2358.

3. Brendan, R.J., Griffin, P.M., Cole, D., Walsh, K.A., Chai, S.J. (2013). Outbreak-associated Salmonella enterica Serotypes and Food Commodities, United States, 1998-2008. Emerging Infectious Diseases, 19 (8), 12391244.

4. Centers for Disease Control and Prevention (CDC). (2010). Investigation update: Multistate outbreak of human Salmonella Montevideo infections.

(http://www.cdc.gov/salmonella/montevideo/).

5. Centers for Disease Control and Prevention (CDC). (2012). Salmonellosis. Outbreak 2012: Multistate Outbreak of Human Salmonella Montevideo Infections Linked to Live Poultry in Backyard Flocks

(http://www.cdc.gov/salmonella/montevideo-0612/index.html).

6. Centers for Disease Control and Prevention (CDC). (2013). Surveillance for Foodborne Disease Outbreaks United States, 2013: Annual Report.(http://www.cdc.gov/foodsafety/pdfs/foo dborne-disease-outbreaks-annual-report-2013508c.pdf).

7. Cevallos-Cevallos, J.M., Gu, G., Danyluk, M.D., van Bruggen, A.H.C. (2012). Adhesion and splash dispersal of Salmonella enterica Typhimurium on tomato leaflets: Effects of rdar morphotype and trichome density. International Journal of Food Microbiology, 160, 58-64.

8. Crump, J.A., Griffin, P.M., Angulo, F.J. (2002). Bacterial contamination of animal feed and its relationship to human illness. Clinical Infectious Diseases, 35, 859-865.

9. European Food Safety Authority (EFSA). (2013). Panel on Biological Hazards (BIOHAZ), Scientific Opinion on the risk posed by pathogens in food of non-animal origin. Part 1 (outbreak data analysis and risk ranking of food/pathogen combinations), Parma, Italy, pp. 1-138.

10. European Food Safety Authority (EFSA). (2015). Manual for reporting on food-borne outbreaks in accordance with Directive 2003/99/EC for information deriving from the year 2014, Technical Report, Published: 27 February 2015.

11. Gaillot, O., Clement, C., Simonet, M., Philippon, A. (1997). Novel transferable beta-lactam resistance with cephalosporinase characteristics in Salmonella enteritidis. Journal of Antimicrobial Chemotherapy, 39, 85-87.

12. Gericke, B., Rische, H., Schmidt, E., Tschäpe, H. (1988). Salmonella Montevideo from a hospital outbreak with different antibiograms determined by a plasmid. Zentralblatt für Bakteriologie, Mikrobiologie und Hygiene B, 186 (2), 180-188. 
13. Gieraltowski, L., Julian, E., Pringle, J., MacDonald, K., Quilliam, D., Marsden-Haug, N., Saathoff-Huber, L., Von Stein, D., Kissler, B., Parish, M., Elder, D., Howard-King, V., Besser, J., Sodha, S., Loharikar, A., Dalton, S., Williams, I., Behravesh, C.B. (2013). Nationwide outbreak of Salmonella Montevideo infections associated with contaminated imported black and red pepper: warehouse membership cards provide critical clues to identify the source. Epidemiology and Infection, 141, 1244-1252.

14. Grimont, P.A.D. and Weill, F.Y. (2007). Antigenic Formulae of the Salmonella Serovars, $9^{\text {th }}$ edition, WHO Colaborating Center for Reference and Research on Salmonella, Institut Pasteur, France.

15. Hamada, K., Tsuji, H., Oshima, K. (2002). Salmonella Serovar Montevideo Involved in a Food Poisoning Outbreak at a Club for Elderly Persons in April 2002 in Hyogo Prefecture. Japanese Journal of Infectious Diseases, 55, 176-177.

16. Institut za javno zdravlje Srbije (2012). Broj obolelih i incidencija od zaraznih bolesti, Republika Srbija.

(http://www.batut.org.rs/download/izvestaji/Broj \%20obolelih\%20i\%20incidencija\%20od\%20zaraznih\%20bolesti\%202012.pdf).

17. Jones, F.T. (2011). A review of practical Salmonella control measures in animal feed. Journal of Applied Poultry Research, 20, 102113.

18. Kim, J.Y., Park, Y.J., Lee, S.O., Song, W., Jeong, S.H., Young, A., Yoo, Y.A., Lee, K.Y. (2004). Case Report: Bacteremia due to Salmonella enterica serotype Montevideo producing plasmid-mediated AmpC $\beta$-Lactamase (DHA-1). Annals of Clinical and Laboratory Science, 34 (2), 214-217.

19. Lapidot, A., Römling, U., Yaron, S. (2006). Biofilm formation and the survival of Salmonella typhimurium on parsley. International Journal of Food Microbiology, 109, 229-233.

20. Lawlor, E., Reinert, L.R.N. (2013). Outbreak of Salmonella Montevideo infections associated with a graduation party - Lincoln County, may 2012. Report by: Elizabeth Lawlor, MS (Kansas Department of Health and Environment), Ladonna Reinert, RN (Lincoln County Health Department) On: February 11, 2013. (http://www.kdheks.gov/epi/download/Grad_Par ty Salmonella Report Final.pdf).

21. McChesney, D.G., Kaplan, G., Gardner, P. (1995). FDA survey determines Salmonella contamination. Feedstuffs, 67, 20-23.

22. Nesse, L.L., Nordby, K., Heir, E., Bergsjoe, B., Vardund, T., Nygaard, H., Holstad, G. (2003).
23. Molecular analyses of Salmonella enterica isolates from fish feed factories and fish feed ingredients. Applied and Environmental Microbiology, 69 (2), 1075-1081.

24. Pilsczek, F.H., Nicholson-Weller, A., Ghiran, I. (2005). Phagocytosis of Salmonella Montevideo by human neutrophils: immune adherence increases phagocytosis, whereas the bacterial surface determines the route of intracellular processing. The Journal of Infectious Diseases, 192, 200-209.

25. Steenackers, H., Hermans, K., Vanderleyden, J., Keersmaecker, S.C.J. (2012). Salmonella biofilms: An overview on occurrence, structure, regulation and eradication. Food Research International, 45, 502-531.

26. Stocker, P., Rosner, B., Werber, D., Kirchner, M., Reinecke, A., Wichmann-Schauer, H., Prager, R., Rabsch, W., Frank, C. (2011). Outbreak of Salmonella Montevideo associated with a dietary food supplement flagged in the Rapid Alert System for Food and Feed (RASFF) in Germany, 2010. Euro Surveill 16(50):pii $=20040$ (http://www.eurosurveillance.org/ViewArticle.as px?Articleld=20040).

27. Switt, M.A.I., den Bakker, H.C., Cummings, C.A., Rodriguez-Rivera, L.D., Govoni G., Raneiri, M.L., Degoricija, L., Brown, S., Hoelzer, K., Peters, J.E., Bolchacova, E., Furtado, M.R., Wiedmann, M. (2012). Identification and characterization of novel Salmonella mobile elements involved in the dissemination of genes linked to virulence and transmission. PLOS One, 7(7), e41247. doi:10.1371/journal.pone.0041247.

28. Threlfall, E.J., Hampton, M.D., Ward, L.R., Richardson, I.R., Lanser, S., Greener T. (1999). Pulsed field gel electrophoresis identifies an outbreak of Salmonella enterica serotype Montevideo infection associated with a supermarket hot food outlet. Communicable Disease and Public Health, 2, 207-209.

29. Vestby, L.K., Møretrø, T., Langsrud, S., Heir, E., Nesse, L.L. (2009). Biofilm forming abilities of Salmonella are correlated with persistence in fish meal- and feed factories. BMC Veterinary Research, 5, 20.

(http://www.biomedcentral.com/1746-148/5/20).

30. World Health Organization (WHO) (2015). Global Foodborne Infections Network, year data viewed. Top 15 Salmonella Serotype list, Top 15 list from a Country parameters, Serbia, Institute of Public Health of Serbia, 2004.

31. www.gov.uk/government/uploads/system/uploa ds/attachment_data/file/348960/pub-salm13chp3.pdf Chapter 3. Reports of Salmonella in sheep and goats. 


\title{
ЕПИДЕМИОЛОШКИ ЗНАЧАJ SALMONELLA ENTERICA SEROVAR MONTEVIDEO И ПОТЕНЦИЈАЛНА УЛОГА ХРАНЕ ЗА ЖИВОТИЊЕ ЗА ЊЕН УЛАЗАК У ЛАНАЦ ИСХРАНЕ
}

\author{
Дубравка С. Миланов ${ }^{1 *}$, Маја Ј. Велхнер ${ }^{1}$, Неђељко Р. Карабасил ${ }^{2}$, Ивана С. Чабаркапа $^{3}$, \\ Љиљана Ђ. Сувајџић ${ }^{4}$ \\ ${ }^{1}$ Научни институт за ветеринарство „Нови Сад“, 21000 Нови Сад, Руменачки пут 20, Србија \\ ${ }^{2}$ Универзитет у Београду, Факултет ветеринарске медицине, 11000 Београд \\ Булевар ослобођења 18, Србија \\ ${ }^{3}$ Универзитет у Новом Саду, Научни институт за прехрамбене технологије у Новом Саду, \\ 21000 Нови Сад, Булевар цара Лазара 1, Србија \\ ${ }^{4}$ Универзитет у Новом Саду, Медицински фракултет, Департман за фрармацију, 21000 Нови Сад, \\ Хајдук Вељкова 3, Србија
}

Сажетак: Храна за животиње је прва карика у ланцу исхране и један од могућих извора Salmonella за животиње, а посредно и људе који конзумирају производе животињског порекла. Значај и улогу салмонела које се установљавају у храни за животиње у појави епидемија салмонелоза веома је тешко проценити, јер се изолати ретко типизирају до серотипа и прави подаци недостају и за храну за животиње и за намирнице анималног порекла. У оквиру реализације пројекта финансираног од стране Министарства за науку и технолошки развој Републике Србије, током две године су сви изолати Salmonella spp. из хране за животиње потврђени и типизирани до серотипа у Националној референтној лабораторији за Salmonella. Идентификовано је 18 различитих серотипова, а 15\% свих изолата односио се на Salmonella ser. Montevideo. Због учестале изолације Salmonella ser. Montevideo из хране за животиње пореклом из фабрика сточне хране на нашем епизоотиолошком подручју (Јужнобачки и Сремски округ), у овом раду износимо доступне податке о значају овог серотипа у појави клиничких салмонелоза код људи, приказе појединачних епидемиолошких истраживања у циљу утврђивања извора инфекције и релевантне чињенице о растућој антимикробној резистенцији Salmonella. Такође, у раду истичемо потребу за јединственим мониторингом над салмонелама на националном нивоу, који ће укључити све карике у ланцу исхране, почевши од хране за животиње и објеката за њихову производњу.

Кључне речи: храна за животиње, ланац исхране, Salmonella ser. Montevideo

Received: 12 August 2015

Accepted: 27 October 2015 